\title{
Absorption Ability of Particulate Matter in Leaves of Street Trees in Jinju City
}

\author{
Min-Gi Cho' ${ }^{1}$ Eon-Ju Jin' ${ }^{1}$ Eun-Ji Bae ${ }^{1}$, Kwang-Soo Lee ${ }^{1}$, Hyun-Shik Moon ${ }^{2,4} *$, and Moo-Ryong Huh ${ }^{3,4}$ \\ ${ }^{1}$ Southern For. Res. Center, Korea For. Res. Insti., Jinju 52828, South Korea \\ ${ }^{2}$ Department of Forest Resources, Gyeongsang National University, Jinju 52828, South Korea \\ ${ }^{3}$ Department of Horticulture, Gyeongsang National University, Jinju 52828, South Korea \\ ${ }^{4}$ Institute of Agriculture \& Life Science, Gyeongsang National University Jinju 52828, South Korea
}

\begin{abstract}
This study was carried out to provide preliminary information to grasp how many particulate matter (PM) which is a problem in urban area are absorbed and removed by street trees. The morphology, size and element composition of PM deposited on leaves of five street trees (Quercus glauca, Q. myrsinaefolia, Ginkgo biloba, Prunus serrulata var. spontanea, and Pinus densiflora) in Jinju city, South Korea were analyzed. The size of PM was classified into three as $\mathrm{PM}_{2.5}(0.2 \sim 2.5 \mu \mathrm{m}), \mathrm{PM}_{10}(2.5 \sim 10 \mu \mathrm{m})$, and $\mathrm{PM}_{100}(10 \sim 100 \mu \mathrm{m})$. The element composition of PM deposited on the leaves at the study sites mainly comprised of $\mathrm{O}, \mathrm{C}, \mathrm{N}$, Si, and Al. The PM at industrial area and university campus was irregular and spherical shape, respectively. Total PM accumulated on the leaf surfaces of $P$. densiflora was 71.65 $\mathrm{\mu g} / \mathrm{cm}^{2}$ at industrial area and $40.66 \mu \mathrm{g} / \mathrm{cm}^{2}$ at university campus, which was significantly higher than the other species. The ratio of $\mathrm{PM}_{2.5}, \mathrm{PM}_{10}$, and $\mathrm{PM}_{100}$ deposited on the leaves was $9.2 \%, 37.0 \%, 53.8 \%$ at industrial area and $15.8 \%, 27.1 \%, 57.1 \%$ at university campus, respectively. P. densiflora deposited the most $\mathrm{PM}_{2.5}, \mathrm{PM}_{10}$ and $\mathrm{PM}_{100}$ in leaf wax at the study sites, which was significantly higher than the other species.
\end{abstract}

Keywords: element composition, in-wax PM, leaf surface PM, urban environment, street trees

\section{Introduction}

Since the industrialization of Korea in the 1970s has continued, the urban population has started to increase rapidly, and air pollution has become an important urban problem consequently. As fine dust, which is a particulate matter (PM) in the air, has recently serious environmental problems in most cities of the world, the United States, since 1997, has set criteria for not just $\mathrm{PM}_{10}$ (fine dust), a particle diameter of less than $10 \mu \mathrm{m}$ but also for $\mathrm{PM}_{2.5}$, of less than $2.5 \mu \mathrm{m}$ (fine particulate matter) (Kim, 2014). Korea as well has been promoting various schemes and policies to reduce $\mathrm{PM}_{2.5}$ since 2015 after working on $\mathrm{PM}_{10}$ in 1995 such as use of clean fuel and introduction of low-pollution vehicles (Ministry of Environment, 2017). In Korea atmospheric environment standards for $\mathrm{PM}_{10}$ and $\mathrm{PM}_{2.5}$ are $50 \mu \mathrm{g} / \mathrm{m}^{3}$ and $25 \mu \mathrm{g} / \mathrm{m}^{3}$ per annum respectively (National Institute of Environmental Research, 2016), 2.5 times more than WHO recommended standards (annually PM 10 $20 \mu \mathrm{g} / \mathrm{m}^{3}, \mathrm{PM}_{2.5} 10 \mu \mathrm{g} / \mathrm{m}^{3}$ ), against which there are many criticism that many regulations are needed to strengthen.

Recently, interest in $\mathrm{PM}_{2.5}$ has been rising more than $\mathrm{PM}_{10}$, at the same time the environmental purification function of

Received: September 11, 2017, Revised: October 9, 2017, Accepted: October 16, 2017

*Comesponding author: hsmoon@gnu.ac.kr 
urban forests has attracted attention (Nguyen et al., 2015). Outside of the country, it has been reported that urban forests are effective for PM absorption and removal (Nowak et al., 2006; Tiwary et al., 2009). Pugh et al. (2012) reported that green walls such as street trees interact with increased PM residence time and reduce PM by up to 60\%. Tallis et al. (2011) used Urban Forest Effects Model and estimated that the street trees in the city absorb $\mathrm{PM}_{10}$ of $852 \sim 2,121$ ton/yr. Because the plant captures $\mathrm{PM}$ on leaf surfaces and absorbs $\mathrm{PM}_{2.5}$ into leaf tissue through their pores, urban street trees act as a particulate matter sink (Treshow, 2002; Yin et al., 2011). In addition, the complex leaf structure of the stem water tube has been reported to be ideal for absorbing PM because it causes turbulent air movement (Popek et al., 2013). In Korea, the National Institute of Forest Science has reported to the media that the urban forests of Hongleung, Seoul, have reduced $\mathrm{PM}_{10}$ and $\mathrm{PM}_{2.5}$ by $25.6 \%$ and $40.9 \%$, respectively, in comparison with the city center (National Institute of Forest Science, 2017). Although the Korea Forest Service has been making policy efforts to expand urban forests to improve the quality of life of urban residents and to improve the living environment which has been worsened by PM, there is no specific study on the PM absorption capacity of urban forests including street roadside trees in Korea.

This study was conducted to investigate the PM and element composition absorbed on the leaf surface of a street trees in Jinju city, Gyeongsangnam-do by classifying $\mathrm{PM}$ into $\mathrm{PM}_{2.5}(0.2 \sim 2.5 \mu \mathrm{m}), \mathrm{PM}_{10}(2.5 \sim 10 \mu \mathrm{m}), \mathrm{PM}_{100}(10 \sim 100 \mu \mathrm{m})$, respectively and measuring the mass of each leaf to evaluate the PM absorption ability of the leaf of the street trees.

\section{Material and Method}

\section{Sampling}

This study was conducted on the leaves of street trees in the industrial area (A) and the university campus (B) located in Jinju, Gyeonggnam Province. In order to minimize the variation by area, samples were collected from street trees located at a moving distance of less than $200 \mathrm{~m}$ in total, and the sampling date was October 15, 2016, during only one day in the two surveyed sites. Therefore, PM concentration in the air and the meteorological conditions were considered to be the same (Fig. 1). The industrial area (A) was located in the center of the factory area called the Sangpyeong Industrial Complex, and the university campus was located at the Gyeongsang National University.

Species to be analyzed are five street trees which are Quercus glauca (hereinafter, Qg), Quercus myrsinaefolia (hereinafter, Qm), Ginkgo biloba (hereinafter Gb), Prunus serrulata var. spontanea (hereinafter Ps), Pinus densiflora

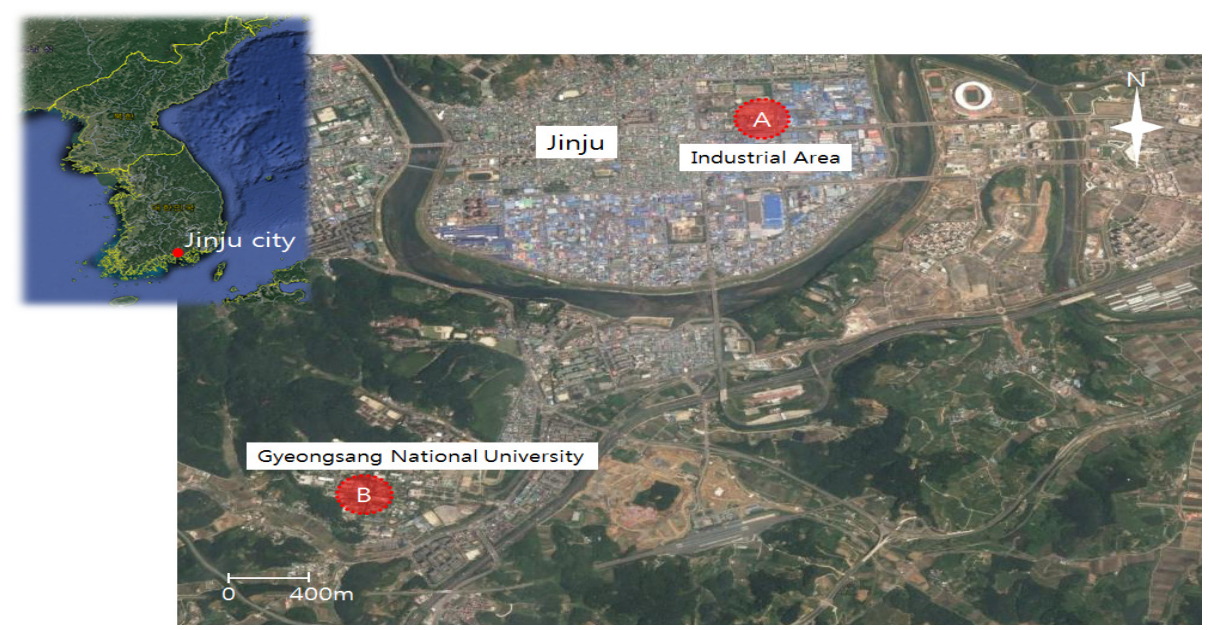

Figure 1. The location map of surveyed sites (From Google map). 
Table 1. The basic characteristics of trees samples at industrial area (A) and university campus (B).

\begin{tabular}{|c|c|c|c|c|c|c|c|c|}
\hline \multirow{2}{*}{ Species } & \multicolumn{2}{|c|}{ Diameter $(\mathrm{cm})$} & \multicolumn{2}{|c|}{ Height (m) } & \multicolumn{2}{|c|}{ Width of crown (m) } & \multicolumn{2}{|c|}{ Timber height $(\mathrm{m})$} \\
\hline & A & B & A & B & A & B & A & B \\
\hline Quercus glanca $(Q g)$ & $20.5 \pm 1.8$ & $21.2 \pm 5.5$ & $5.6 \pm 0.5$ & $5.5 \pm 1.3$ & $2.9 \pm 0.4$ & $3.0 \pm 0.8$ & $2.8 \pm 0.4$ & $1.9 \pm 0.6$ \\
\hline Quercus myrsinaefolia $(\mathrm{Qm})$ & $21.1 \pm 3.0$ & $22.9 \pm 2.7$ & $7.1 \pm 0.2$ & $5.8 \pm 1.0$ & $2.6 \pm 0.5$ & $3.5 \pm 0.4$ & $2.7 \pm 0.3$ & $1.7 \pm 0.3$ \\
\hline Ginkgo biloba $(G b)$ & $35.6 \pm 4.2$ & $33.4 \pm 8.8$ & $7.0 \pm 1.0$ & $10.7 \pm 1.2$ & $2.5 \pm 0.3$ & $3.5 \pm 0.7$ & $2.5 \pm 0.0$ & $2.3 \pm 1.4$ \\
\hline Prunus serrulata var. spontanea $(P s)$ & $37.6 \pm 3.3$ & $32.0 \pm 7.2$ & $8.8 \pm 0.3$ & $4.3 \pm 1.0$ & $3.7 \pm 0.3$ & $3.4 \pm 0.5$ & $3.7 \pm 0.6$ & $1.7 \pm 0.1$ \\
\hline Pinus densiflora $(P d)$ & $23.7 \pm 0.6$ & $27.0 \pm 1.3$ & $5.0 \pm 1.0$ & $5.0 \pm 1.0$ & $2.5 \pm 0.3$ & $2.9 \pm 0.4$ & $1.1 \pm 0.1$ & $2.6 \pm 0.5$ \\
\hline
\end{tabular}

Data are mean $\pm \mathrm{SD}, \mathrm{n}=5$.

(hereinafter $P d$ ). These trees are showing average growth within the surveyed sites. Table 1 shows the characteristics of the trees.

Sampling was carried out on five trees per species, with no damage by insects and pests among the leaves located in four orientations at a height of 2 to $3 \mathrm{~m}$. To prevent PM from being dropped out of leaves during sampling, leaf specimens were cut into scraps in paper bags and stored in a refrigerator maintained at ambient temperature until they were transferred to the laboratory due to PM's vulnerability to static electricity (Song et al., 2015). In this study, leaf samples were taken from 25 days when there was no precipitation because the leaves of the plant can adsorb dust to the maximum at 26 days (Liu et al., 2013).

\section{Analysis on element composition of PM}

Scanning electron microscope (SEM) was used to analyze the position of PM absorption. The leaves of broad-leaved species such as $Q g$ were cut to the size $\left(1 \mathrm{~cm}^{2}\right)$ that can be observed with a microscope to avoid the vein at the middle point, and $P d$ was cut in half at the middle point of the leaf while the prepared sample was attached to a microscope, using double-sided adhesive tape. These samples were subjected to gold coating to improve electrical conductivity, and then randomly selected samples were taken through SEM (Genesis-1000, Emcrafts) and the components were analyzed using Energy Dispersive X-ray (EDX) to be analyzed up to $0.1 \%$ wt. PM was classified into ones with irregular shape, ones with corners, spherical particles, carbon particles, and bio-particle for analysis.

\section{Mass spectrometric analysis of PM}

The PM absorbed on the leaves were collected and analyzed through the method of Dzierzanowski et al. (2011). The PM attached to the surface of the leaves was completely removed using distilled water. The washed water was filtered using a filter and filtering was conducted first for the largest dust size and in order of size. At this time, filters were used in sizes of $100 \mu \mathrm{m}, 10 \mu \mathrm{m} 3.0 \mu \mathrm{m}$, and $0.2 \mu \mathrm{m}$ (Millipore, USA). The filter was first dried for two hours in a dryer at $60^{\circ} \mathrm{C}$ prior to be used for filtration and then measured. After filtering the PM, the weight was measured using an electronic balance (Ohaus: PAG214, USA). In order to measure the PM absorbed on the leaf wax layer, the same method was conducted as was done on the surface of leaf but chloroform was used in place of distilled water in order to decompose the wax layer. After filtration, the PM deposited on the wax layer was analyzed. The area of each leaf was measured using LI-3000c and LI-3050c (leaf area analyzer, LI-COR, USA) to analyze the mass of PM per unit area absorbed on the leaves. All analyzes were performed in three times repeatedly. 
The collected data were analyzed through the method of ANOVA to see and analyze the significant difference in PM's absorption ability by species and also the significant differences between the two groups were also analyzed. SPSS (Statistical Package for Social Science) v. 18 statistical package program was used for analysis.

\section{Results and Discussion}

\section{PM element and Morphology}

The element composition of PM absorbed on the leaves of five street trees planted in Jinju industrial area (A) and university campus (B) were analyzed. In both areas, the elemental components of PM absorbed on the leaf of the street trees were $\mathrm{C}, \mathrm{N}, \mathrm{O}, \mathrm{Na}, \mathrm{Mg}, \mathrm{Al}, \mathrm{Si}, \mathrm{S}, \mathrm{Cl}, \mathrm{K}, \mathrm{Ca}, \mathrm{Ti}, \mathrm{Fe}$ and $\mathrm{Pb}$ (Fig. 2). Although there is a difference in the content of each element of PM, common main constituents are $\mathrm{O}, \mathrm{C}, \mathrm{N}, \mathrm{Si}$, Al, etc. of about $85 \%$ or more. Among those making up PM, C, $\mathrm{O}, \mathrm{Si}, \mathrm{Fe}$, and $\mathrm{Ca}$, can be derived from human activities but are mainly derived from natural resources, and $\mathrm{Fe}, \mathrm{CL}, \mathrm{Pb}$ and Ti have been reported to be generated by human activities. When comparing the Song et al. (2015) which reported that the main constituents of PM in five evergreen trees in Beijing, China are C, O, Si, Ca, Na, Mg and Dai et al. (2013) which reported that PM absorbed in Sophora japonica in Beijing, China mainly consists of C, O, Si, Ca, Al, etc., the elements that are consistent with this study appeared. $\mathrm{Pb}$, which is known to be harmful to human health, is released mainly by the combustion of fossil fuels such as vehicle exhaust and coal (Song et al., 2016). However, in industrial areas, $\mathrm{Pb}$ is absorbed on leaves of $\mathrm{Qm}$, which allows the presumption that the exhaust gas from vehicles and factories is the main cause.

As the morphology of PM is one method used to identify information of particulate matter, particles with irregular
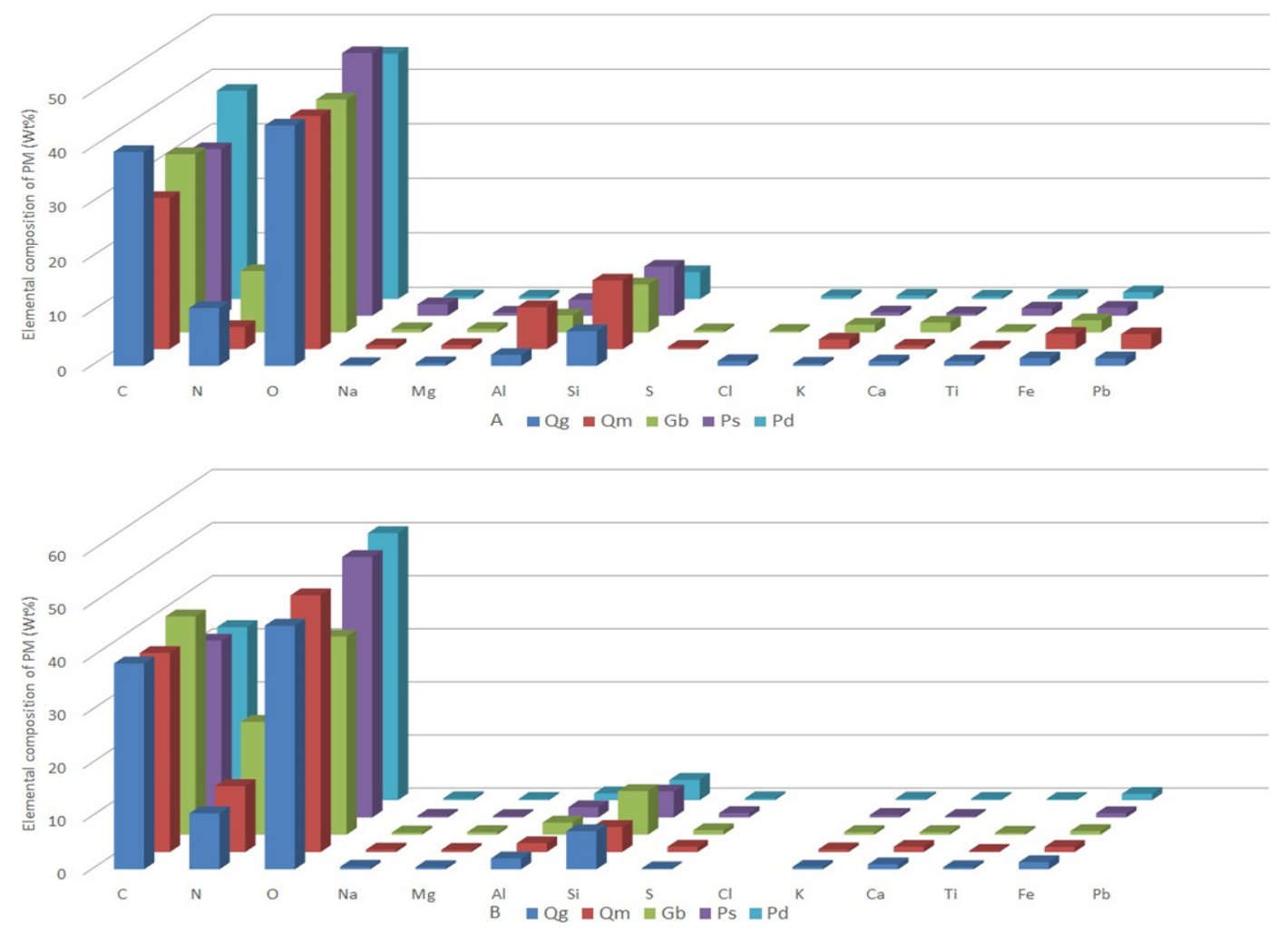

Figure 2. Element composition of particulate matter (PM) on the leaves of five street trees at industrial area (A) and university campus (B). The abbreviations of species are shown in Table 1. 
shapes and angled corners are dust particles that have been worn out of matters, coming from industrial or transportation means. On the other hand, particles from the combustion of biomass resources such as coal are easily identified as spherical, smooth surfaces and regular shapes. Carbon particle aggregates larger than $10 \mu \mathrm{m}$, such as soot, are aggregates of fine or ultra-fine particles derived from biomass burning such as automobile exhaust and coal. Bio-particles such as spores and pollen particles from biological sources can also be identified through their diameters ranging from 20 to $50 \mu \mathrm{m}$ (Song et al., 2015).

The analysis of the morphological characteristics of PM absorbed on the leaves of street trees in the industrial area and university campus (Fig. 3) shows that the industrial areas have irregular shapes in general. The $Q g$ and $Q m$ in the industrial area show an irregular shape with no specific shape and $\mathrm{Pb}, \mathrm{Fe}$, and $\mathrm{Mg}$ are the elemental components of PM, which seems that major cause are vehicle exhaust and industrial gas. $G b, P s$, and $P d$ are irregularly shaped with a little circular shape, which was judged that the main cause is $\mathrm{Ca}$ and $\mathrm{Cl}$ stemming from biomass particles such as dust and coal in buildings (Song et al., 2015). On the other hand, those found in the university campus are relatively spherical. The size is in the range of about $20 \sim 50 \mu \mathrm{m}$, which is judged as bio particles.

\section{Amount of PM absorbed on the surface of leaf}

The amount of absorbed PM on leaf surface was analyzed (Fig. 4). In the industrial area (A), the amount of PM

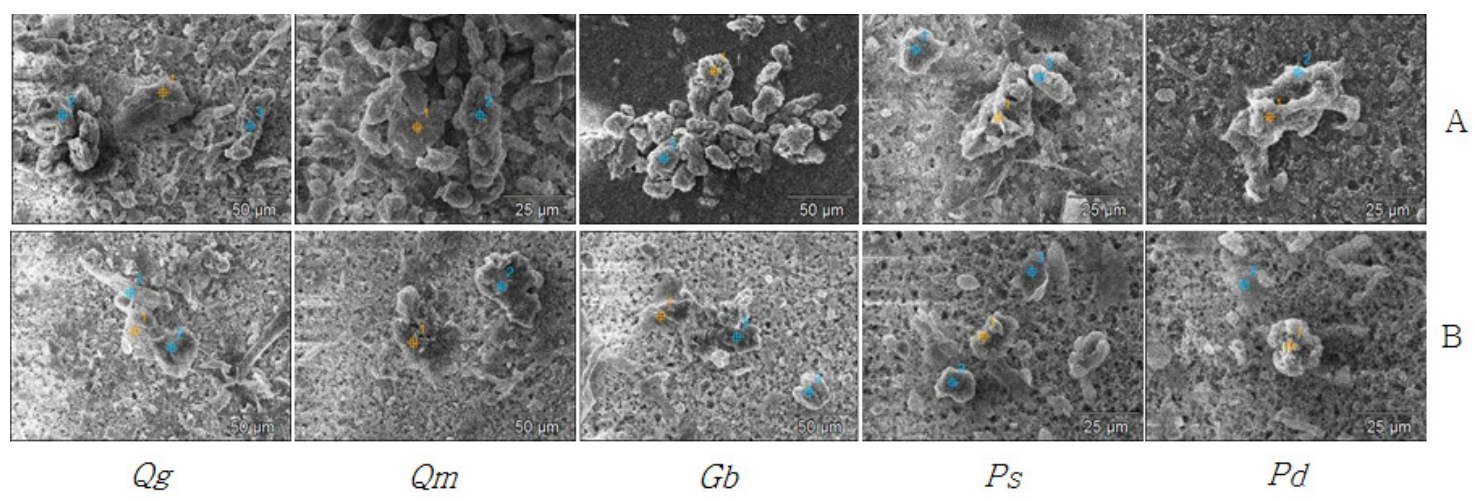

Figure 3. The size and morphology of PM on the leaf surfaces used for the elemental composition test at industrial area (A) and university campus (B). The abbreviations of species are shown in Table 1.

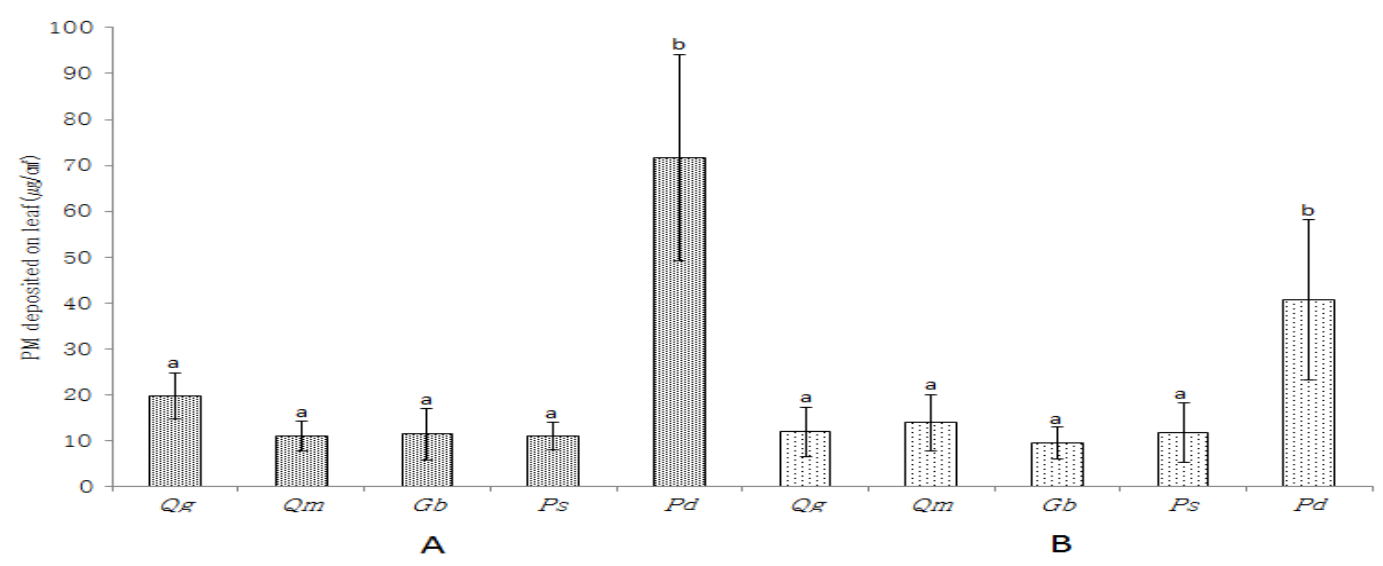

Figure 4. Total PM deposited on the leaves of five street trees at industrial area (A) and university campus (B). Data are mean $\pm S E, n=15$. The abbreviations of species are shown in Table 1. Different letters indicates statistical significance at the $p=0.05$ level. 
absorption on the Pd leaf surface was $71.65 \mu \mathrm{g} / \mathrm{cm}^{2}$, which was significantly higher than those of other species, followed by $Q g\left(19.79 \mu \mathrm{g} / \mathrm{cm}^{2}\right), G b\left(11.42 \mu \mathrm{g} / \mathrm{cm}^{2}\right), P s\left(11.00 \mu \mathrm{g} / \mathrm{cm}^{2}\right)$, and $Q m\left(10.89 \mu \mathrm{g} / \mathrm{cm}^{2}\right)$. In the university campus (B), PM absorption amount of $P d$ leaf surface was $40.66 \mu \mathrm{g} / \mathrm{cm}^{2}$, which was significantly higher than other species, followed by Qm $\left(13.85 \mu \mathrm{g} / \mathrm{cm}^{2}\right), \operatorname{Qg}\left(11.91 \mu \mathrm{g} / \mathrm{cm}^{2}\right), P s\left(11.69 \mu \mathrm{g} / \mathrm{cm}^{2}\right)$ and $G b\left(9.48 \mu \mathrm{g} / \mathrm{cm}^{2}\right)$ in that order. Though as for PM absorption of Pinus spp. it has different from the study that there is not big differences between conifers and hardwoods (Nguyen et al., 2015), it is consistent with the study that PM was more easily absorbed on thin and narrow needles than broad-leaved trees (Tallis et al., 2011; Paoletti et al., 2011), indicating that the PM absorption power of coniferous leaves is superior. The PM absorption amount of $P d\left(40.7 \mu \mathrm{g} / \mathrm{cm}^{2}\right)$ in the university campus was lower than 150 and $90 \mu \mathrm{g} / \mathrm{cm}^{2}$ (Song et al., 2015) of Lacebark Pine tree in Beijing, China and Manchurian red pine, However, the absorption amount of $P d$ 's PM in the industrial area was $71.7 \mu \mathrm{g} / \mathrm{cm}^{2}$, which was similar to $70 \mu \mathrm{g} / \mathrm{cm}^{2}$ (Sæbø et al., 2012) of Norwegian pine in Europe. There was no significant difference between the amount of absorption of $Q m$, which is from 10.9 to $19.8 \mu \mathrm{g} / \mathrm{cm}^{2}$ and $9.7 \mu \mathrm{g} / \mathrm{cm}^{2}$ (Popek et al., 2013) and $18 \mu \mathrm{g} / \mathrm{cm}^{2}$ of Northern red oak. (Sæbø et al., 2012) (9.48 11.42 $\mu \mathrm{g} / \mathrm{cm}^{2}$ ). However, $G b\left(9.48 \sim 11.42 \mu \mathrm{g} / \mathrm{cm}^{2}\right)$ was slightly lower than $16.1 \mu \mathrm{g} / \mathrm{cm}^{2}$ of Popek et al. (2013). These results indicate that the PM absorption capacity is different even in the same genus or the same species, which makes it possible to estimate that various factors such as the concentration of PM in the atmosphere, the growth environment, and the characteristics of the plant species are acting.

As a result of analysing the absorption capacity of the street trees in the industrial area and the university campus (Table 2), the $\mathrm{PM}_{2.5}$ absorbed on the surface of the street trees in the industrial area was $9.12 \%$ of the total PM weight. The most abundant absorption amount of $\mathrm{PM}_{2.5}$ was found to be $7.27 \mu \mathrm{g} / \mathrm{cm}^{2}$ in $P d$ and the lowest was $0.12 \mu \mathrm{g} / \mathrm{cm}^{2}$ in $Q m$. The other species ranged from 0.52 to $1.89 \mu \mathrm{g} / \mathrm{cm}^{2}$, and the ratio of $\mathrm{PM}_{2.5}$ to total $\mathrm{PM}$ weight was $9.2 \%$ on average. The absorption

Table 2. Total amount of surface PM deposited on the leaves of five street trees with respect to three size fractions at industrial area (A) and university campus (B). Data are mean $\pm S D, n=5$.

\begin{tabular}{|c|c|c|c|c|c|c|c|}
\hline \multirow[b]{2}{*}{ Area } & \multirow[b]{2}{*}{ Species $^{2}$} & \multicolumn{3}{|c|}{ The quality of PM on leaf $\left(\mu \mathrm{g} / \mathrm{cm}^{2}\right)$} & \multicolumn{3}{|c|}{ The percentage of different fractions (\%) } \\
\hline & & $\begin{array}{c}\mathrm{PM}_{2.5} \\
(0.2-2.5 \mu \mathrm{m})\end{array}$ & $\begin{array}{c}\mathrm{PM}_{10} \\
(2.5-10 \mu \mathrm{m})\end{array}$ & $\begin{array}{c}\mathrm{PM}_{100} \\
(10-100 \mu \mathrm{m})\end{array}$ & $\begin{array}{c}\mathrm{PM}_{2.5} \\
(0.2-2.5 \mu \mathrm{m})\end{array}$ & $\begin{array}{c}\mathrm{PM}_{10} \\
(2.5-10 \mu \mathrm{m})\end{array}$ & $\begin{array}{c}\mathrm{PM}_{100} \\
(10-100 \mu \mathrm{m})\end{array}$ \\
\hline \multirow{6}{*}{ A } & $Q g$ & $0.52 \pm 0.25 \mathrm{a}^{\mathrm{y}}$ & $4.60 \pm 0.97 \mathrm{a}$ & $8.35 \pm 2.35 \mathrm{a}$ & 3.9 & 34.1 & 62.0 \\
\hline & $Q m$ & $0.12 \pm 0.11 \mathrm{a}$ & $1.00 \pm 0.87 \mathrm{a}$ & $4.93 \pm 1.00 \mathrm{a}$ & 2.0 & 16.5 & 81.5 \\
\hline & $G b$ & $0.89 \pm 0.48 \mathrm{a}$ & $6.08 \pm 3.80 \mathrm{a}$ & $2.44 \pm 0.61 \mathrm{a}$ & 9.5 & 64.6 & 25.9 \\
\hline & Ps & $1.20 \pm 0.53 \mathrm{a}$ & $3.12 \pm 0.22 \mathrm{a}$ & $3.66 \pm 1.22 \mathrm{a}$ & 15.0 & 39.1 & 45.9 \\
\hline & $P d$ & $7.27 \pm 4.88 \mathrm{~b}$ & $14.77 \pm 1.71 \mathrm{~b}$ & $25.78 \pm 7.09 \mathrm{~b}$ & 15.2 & 30.9 & 53.9 \\
\hline & Average & 2.00 & 5.91 & 9.03 & 9.2 & 37.0 & 53.8 \\
\hline \multirow{6}{*}{ B } & $Q g$ & $0.77 \pm 0.61 \mathrm{a}$ & $2.87 \pm 1.71 \mathrm{~b}$ & $3.29 \pm 1.64 \mathrm{a}$ & 11.2 & 41.4 & 47.4 \\
\hline & $Q m$ & $0.28 \pm 0.19 \mathrm{a}$ & $2.62 \pm 0.92 \mathrm{~b}$ & $3.69 \pm 1.33 \mathrm{a}$ & 4.2 & 39.8 & 56.0 \\
\hline & $G b$ & $0.95 \pm 0.28 \mathrm{a}$ & $0.88 \pm 0.40 \mathrm{a}$ & $2.15 \pm 1.52 \mathrm{a}$ & 23.9 & 22.1 & 54.0 \\
\hline & Ps & $0.21 \pm 0.21 \mathrm{a}$ & $1.28 \pm 0.60 \mathrm{a}$ & $4.36 \pm 4.30 \mathrm{a}$ & 3.7 & 21.8 & 74.5 \\
\hline & $P d$ & $9.07 \pm 6.44 \mathrm{~b}$ & $2.59 \pm 1.08 \mathrm{a}$ & $13.55 \pm 6.41 \mathrm{~b}$ & 36.0 & 10.3 & 53.7 \\
\hline & Average & 2.26 & 2.05 & 5.41 & 15.8 & 27.1 & 57.1 \\
\hline
\end{tabular}

${ }^{\mathrm{z}}$ The abbreviations of species are shown in Table 1.

${ }^{\mathrm{y}}$ Different letters indicates statistical significance at the $p=0.05$ level. 
ability of $\mathrm{PM}_{10}$ and $\mathrm{PM}$ was also highest in the leaves of $P d$, which was $37.0 \%$ and $53.8 \%$, respectively against total weight. The $\mathrm{PM}_{2}$. and $\mathrm{PM}$ of the $P d$ trees in the university campus were $9.07 \mu \mathrm{g} / \mathrm{cm}^{2}$ and $13.55 \mu \mathrm{g} / \mathrm{cm}^{2}$, respectively, significantly higher than those of other trees as in the case of the industrial area and the weight ratio represent $37.0 \%$ and $53.8 \%$ against the total $\mathrm{PM}$ weight. The amount of $\mathrm{PM}_{10}$ absorption of $P d$ was $2.59 \mu \mathrm{g} / \mathrm{cm}^{2}$, which was not significantly different from $2.62 \mu \mathrm{g} / \mathrm{cm}^{2}$ of $Q g$ and $2.87 \mu \mathrm{g} / \mathrm{cm}^{2}$ of $Q m$ but seems slightly lower than them. The absorption of $\mathrm{PM}_{100}$ by species showed that $P d$ had 3 5 times higher absorption ability than the other species, except $\mathrm{PM}_{10}$ absorption amount of $P d$ on university campus, indicating the $P d$ is more efficient in removing $\mathrm{PM}$ than other tree species. The ratio of $\mathrm{PM}_{2.5}$, $\mathrm{PM}_{10}$, and $\mathrm{PM}_{100}$ to the total $\mathrm{PM}$ weight was $9.2 \%, 37.0 \%$, and $53.8 \%$ in the industrial area. However, the ratio of $\mathrm{PM}_{2.5}$ to the species of street trees varied from $2.0 \%$ of $Q m$ to $15.2 \%$ of $P d$. indicating the difference was very large between different tree species. In the case of university campus, the ratio of $\mathrm{PM}_{2.5}, \mathrm{PM}_{10}$, and $\mathrm{PM}_{100}$ were $15.8 \%, 27.1 \%$, and 57.1\% on average, respectively, showing the differences in value and has similarities to the industrial area. The $\mathrm{PM}_{2.5}$ absorption ability was $3.7 \%$ of $P s$ and $36.0 \%$ of $P d$, indicating large differences according to species. The results of this study are summarized as follows: $\mathrm{PM}_{100}>\mathrm{PM}_{10}>\mathrm{PM}_{2.5}$ in $\mathrm{PM}$ absorption ability. This is consistent with Dzierżanowski et al. (2011), Popek et al. (2013) and Song et al. (2016).

Due to the large amount of traffic and the use of large amounts of fossil fuels, the concentration of atmospheric PM around the industrial area is high and therefore, it is expected that more PM will be absorbed in the street trees. In this study $\mathrm{PM}_{10}$ and $\mathrm{PM}_{100}$ were absorbed on the leaves of the street trees in the industrial area. However, except for Ps, $\mathrm{PM}_{2.5}$ was found to be more absorbed on the street trees in university campus. The street trees have the effect of purifying the air by removing the atmospheric PM, but the PM containing the heavy metal particles is toxic by destroying the leaf cell tissue of the plant (Nguyen et al., 2015). There should be more studies coming such as on PM concentration in the atmosphere, removal of PM through the plant, physiological ecological effect of PM on the plants and so on.

\section{The amount of PM absorbed into wax layer}

As the PM absorbed on the wax layer of the plant leaves are permanently fixed, street trees play an important role in PM removal (Song et al., 2015). The PM absorbed on leaf wax layer of five tree species in industrial area (A) and university campus (B) were analyzed. In the industrial area (Fig. 5A), $\mathrm{PM}_{2.5}, \mathrm{PM}_{10}$, and $\mathrm{PM}_{100}$ absorbed into $P d$ 's wax layers were

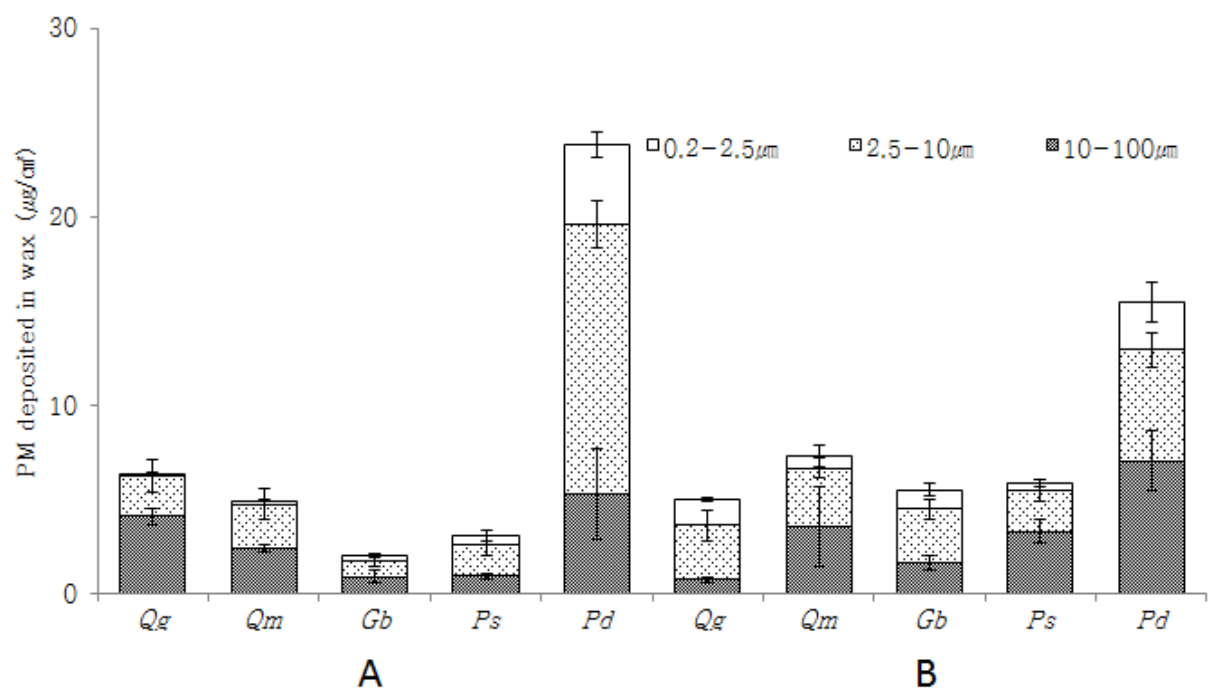

Figure 5. PM deposited in the wax of five street trees at industrial area (A) and university campus (B). Data are mean $\pm \mathrm{SE}$, $\mathrm{n}=5$. The abbreviations of species are shown in Table 1. 
4.27, 14.30 and $5.27 \mu \mathrm{m} / \mathrm{cm}^{2}$, respectively, indicating that $\mathrm{PM}_{10}$ is found to be most absorbed and followed by $Q g$, showing the absorption amount of $\mathrm{PM}_{2.5}, \mathrm{PM}_{10}$, and $\mathrm{PM}_{100}$ were $0.08,2.16$ and $4.08 \mu \mathrm{m} / \mathrm{cm}^{2}$, respectively. The total amount of PM absorbed on the wax layer of $Q m, P s$ and $G b$ leaves were 4.83, 3.02 and $2.02 \mu \mathrm{m} / \mathrm{cm}^{2}$, respectively, showing no big difference between different tree species. In the university campus (Fig. 5B), the amount of PM absorbed on the wax layer of $P d$ leaves was $15.45 \mu \mathrm{m} / \mathrm{cm}^{2}$, which was significantly higher than that of other species. The absorption amounts of $\mathrm{PM}_{2.5}, \mathrm{PM}_{10}$, and $\mathrm{PM}_{100}$ were 2.54, 5.88 and $7.03 \mu \mathrm{m} / \mathrm{cm}^{2}$, respectively, highest absorption of $\mathrm{PM}_{100}$ unlike the industrial area. The amount of absorbed PM was higher in the order of $Q m\left(7.26 \mu \mathrm{m} / \mathrm{cm}^{2}\right), P s\left(5.84 \mu \mathrm{m} / \mathrm{cm}^{2}\right), G b\left(5.50 \mu \mathrm{m} / \mathrm{cm}^{2}\right)$ and $Q g\left(4.98 \mu \mathrm{m} / \mathrm{cm}^{2}\right)$. The total amount of PM absorbed on the $P d$ wax layer in both areas was significantly higher than the other species. This was different from Song et al. (2015) reported that the amount of PM absorbed on the wax layer of Pinus spp. was not significantly different from that of Juniperus, Euonymus, and Platycladus plants. In comparison between the two areas, $P d$ and $Q g$ showed higher absorption in the industrial area than in the university campus, but in other species more PM was removed by the wax layer in the plants of the campus. Dzierzanowskii et al. (2011) reported that $\mathrm{PM}_{10}$ is detected more in the wax layer than leaves, and Popek et al. (2013) reported that the amount of absorbed PM varies depending on the characteristics of the wax layer such as thickness, composition and structure. Therefore, an analysis of the morphological characteristics of the wax layer by tree species should be performed additionally (Burkhardt, 2010).

In order to analyze the function of urban forests including street trees for the reduction of PM in urban areas, a study on the relationship between the characteristics of leaves and PM absorption with the removal of PM from certain plants (Beckett et al., 1998; Freer-Smith et al., 2005; Nguyen et al., 2015) have been actively carried out overseas. However, related studies are almost nothing in Korea except for the studies such as PM removal effect of foliage plant (Kwon and Park, 2014), indoor space modeling and ultra fine dust and soot particle removal of five tree species (Pinus densiflora, Taxus cuspidata, Platanus occidentalis, Zelkova serrata, Ginkgo biloba) in a chamber $(400(\mathrm{~L}) \times 400(\mathrm{~W}) \times 400(\mathrm{H}) \mathrm{mm})$ where air purifying facility of the biofilter is made of acrylic resin (Hwang et al., 2011). In this study, the PM absorption capacity of $P d$ was highest, while coniferous trees were more effective in absorption and removal of PM than broad-leaf trees (Beckett et al., 1998). However, coniferous trees were less resistant to pollutants derived from automobile exhaust gas and in a place where deicer is used during the winter, the species is not suitable as street trees (Nguyen et al., 2015). It has also been reported that rough surface of leaves in broad-leaf trees are more effective for PM absorption and removal than soft leaves (Beckett et al., 2000; Hwang et al., 2011). Though this study analyzed only the PM absorption amount of five tree species in the street of Jinju city, Gyeongnam, it can be expected to be used as basic information in many cases such as selection of street tree species to remove PM in the atmosphere in the future.

\section{Conclusions}

The analysis of the morphological characteristics of PM absorbed on the leaves of street trees shows that the industrial areas have irregular shapes, those found in the university campus are relatively spherical. The ratio of $\mathrm{PM}_{2.5}, \mathrm{PM}_{10}$, and $\mathrm{PM}_{100}$ to the total $\mathrm{PM}$ weight was $9.2 \%, 37.0 \%$, and $53.8 \%$ in the industrial area. However, the ratio of $\mathrm{PM}_{2.5}$ to the species of street trees varied from $2.0 \%$ of Quercus myrsinaefolia to $15.2 \%$ of Pinus densiflora indicating the difference was very large between different tree species. The total amount of PM absorbed on the $P$. densiflora wax layer in both areas was significantly higher than the other species. P. densiflora and Q. glauca showed higher absorption in the industrial area than in the university campus, but in other species more PM was removed by the wax layer in the plants of the campus. The PM absorption capacity of $P$. densiflora was highest in this study, but coniferous trees were less resistant to pollutants 
derived from automobile exhaust gas and in a place where deicer is used during the winter, the coniferous species is not suitable as street trees. The removal of atmospheric PM from the urban area may be effective in improving the air quality by using the PM removal ability of the street trees. However, it is thought to be more effective in improving the air quality by studying the PM absorption ability of various species in urban forests with a certain area. As shown in this study, the PM absorption capacity of pine trees is better than other species. However, since the environment in which pine trees can be utilized in urban areas is slightly limited, the PM absorption capacity of various plant species constituting urban forests should be analyzed, which is expected to be used as basic data for composition and management of urban forest in the future.

\section{References}

Beckett, K. P., P. H. Freer-Smith, and G. Taylor. 1998. Urban woodlands: their role in reducing the effects of particulate pollution. Environ. Pollut. 99(3):347-360. DOI: 10.1016/S0269-7491(98) 00016-5

Beckett, K. P., P. H. Freer-Smith, and G. Taylor. 2000. Effective tree species for local air quality management. J. Arboric. 26(1):12-19.

Burkhardt, J. 2010. Hygroscopic particles on leaves: nutrients or desiccants? Ecol. Monogr. 80(3):369-399. DOI: 10.1890/09-1988.1

Dai, S. D., K. M. Ma, L. Bao, T. Zhang, and D. Zhang. 2013. Distribution of particle matters and contamination of heavy metals in the foliar dust of Sophora japonica in parks and their neighboring roads in Beijing. Acta Sci. Circumst. 33(1):154-162.

Dzierżanowski, K., R. Popek, H. Gawrońska, A. Sæbø, and S. W. Gawroński. 2011. Deposition of particulate matter of different size fractions on leaf surfaces and in waxes of urban forest species. Int. J. Phytoremediation. 13(1):1037-1046. DOI: $10.1080 / 15226514.2011 .552929$

Freer-Smith, P. H., K. P. Beckett, and G. Taylor. 2005. Deposition velocities to Sorbus aria, Acer campestre, Populus deltoides $\times$ trichocarpa 'Beaupré', Pinus nigra and $\times$ Cupressocyparis leylandii for coarse, fine and ultra-fine particles in the urban environment. Environ. Pollut. 133(1):157-167. DOI: 10.1016/j.envpol.2004.03.031

Hwang, H. J., S. J. Yok, and K. H. Ahn. 2011. Experimental investigation of submicron and ultrafine soot particle removal by tree leaves. Atmos. Environ. 45(38):6987-6994. DOI:10.1016/j.atmosenv. 2011.09.019

Kim, W. S. 2014. Management plan for ultrafine dust $\left(\mathrm{PM}_{2.5}\right)$ in Seoul. The Seoul Institute Policy Report 182. Retrieved from https://www.si.re.kr/sites/default/files/pol_182.pdf

Kwon, K. J. and B. J. Park. 2014. Removal particulate matters of four foliage plant-based biofilter. J. Agric. Sci. Chungbuk Nat'l Univ. 30(2):157-160.

Liu, L., D. Guan, and Y. D. Chen. 2013. Morphological structure of leaves and dust-retaining capability of common street trees in Guangzhou Municipality. Acta Ecol. Sinica, 33(8):2604-2614.

Ministry of Environment, 2017. Comprehensive plan for fine dust management. Retrived from http://www.me.go.kr/ issue/finedust $4 /$

National Institute of Forest Science. 2017, May 30. Ecosystem service evaluation and management technology development of Urban forest. Retrieved from https://www.forest.go.kr

National Institute of Environmental Research. 2016. Annual Report of Air Quality in Korea 2015. Ministry of Environment. Retrieved from http://webbook.me.go.kr/DLi-File/NIER/09/5618423.pdf

Nguyen, T., X. Yu, Z. Zhang, M. Liu, and X. Liu. 2015. Relationship between types of urban forest and $\mathrm{PM}_{2.5}$ capture at three growth stages of leaves. J. Environ. Sci. 27(1):33-41. DOI: 10.1016/j. jes.2014.04.019

Nowak, D. J., D. E. Crane, and J. C. Stevens. 2006. Air pollution removal by urban trees and shrubs in the United States. Urban For. Urban. Green. 4(3):115-123. DOI: 10.1016/j.ufug.2006.01.007 
Paoletti, E., T. Bardelli, G. Giovannini, and L. Pecchioli. 2011. Air quality impact of an urban park over time. Procedia Environ. Sci. 4:10-16. DOI: 10.1016/j.proenv.2011.03.002

Popek, R., H. Gawrońska, M. Wrochna, S. W. Gawroński, and A. Sæbø. 2013. Particulate matter on foliage of 13 woody species: deposition on surfaces and phytostabilisation in waxes - a 3-year study. Int. J. Phytoremediation. 15(3):245-256. DOI: $10.1080 / 15226514.2012 .694498$

Pugh, T. A., A. R. MacKenzie, J. D. Whyatt, and C. N. Hewitt. 2012. Effectiveness of green infrastructure for improvement of air quality in urban street canyons. Environ. Sci. Technol. 46(14):7692- 7699. DOI: 10.1021/es300826w

Sæbø, A., R. Popek, B. Nawrot, H. M. Hanslin, H. Gawronska, and S. W. Gawronski. 2012. Plant species differences in particulate matter accumulation on leaf surfaces. Sci. Total Environ. 427:347-354. DOI: 10.1016/j.scitotenv.2012.03.084

Song, J. M., J. O. Bu, W. H. Kim, H. J. Ko, and C. H. Kang. 2016. Composition and emission characteristics of fine particulate matters at the 1100 Site of Mt. Halla during 2011-2012. Anal. Sci. Technol. 29(5):209-218. DOI: 10.5806/AST.2016.29.5.209

Song, Y., B. A. Maher, F. Li, X. Wang, X. Sun, and H. Zhang. 2015. Particulate matter deposited on leaf of five evergreen species in Beijing, China: source identification and size distribution. Atmos. Environ. 105:53-60. DOI: 10.1016/ j.atmosenv.2015.01.032

Tallis, M., G. Taylor, D. Sinnett, and P. Freer-Smith. 2011. Estimating the removal of atmospheric particulate pollution by the urban tree canopy of London, under current and future environments. Lands. Urb. Plann. 103(2):129-138. DOI: 10.1016/j.landurbplan.2011.07.003

Tiwary, A., D. Sinnett, C. Peachey, Z. Chalabi, S. Vardoulakis, T. Fletcher, and T. R. Hutchings. 2009. An integrated tool to assess the role of new planting in $\mathrm{PM}_{10}$ capture and the human health benefits: a case study in London. Environ. Pollut. 157(10):2645-2653. DOI: 10.1016/j.envpol.2009. 05.005

Treshow, M. and J. N. B. Bell. 2002. Air Pollution and Plant Life. New York, USA: John Wiley and Sons.

Yin, S., Z. Shen, P. Zhou, X. Zou, S. Che, and W. Wang. 2011. Quantifying air pollution attenuation within urban parks: An experimental approach in Shanghai, China. Environ. Pollut. 159(8):2155-2163. DOI: 10.1016/j.envpol.2011.03.009 